\title{
The effectiveness of EU crisis response in Afghanistan, Iraq and Mali
}

\author{
Ingo Peters, Enver Ferhatovic, Rabea Heinemann \\ and Sofia Sturm
}

\section{Introduction}

How effective is the EU's crisis response policy in terms of its CSDP missions in Afghanistan, Iraq and Mali, that is, in the EU's selfdefined extended neighbourhood? Are the crisis responses conservative and constrained (crisis management) or emancipatory and ambitious (crisis transformation)? These are pertinent questions guiding the social sciences discourse on EU foreign policy in general and on the appropriateness of EU crisis response policy in particular. To the first question, the debate has been focused for some years on the issues of the 'actorness and power' of the EU as an international actor. A salient part of this discourse has been the issue of foreign policy effectiveness, encompassing contributions varying between degrees of dismissal or praise of EU performance, also in comparison to other international actors. ${ }^{1}$ The second question relates to the debate on EU peacebuilding in the wider sense and the prevalent empirical evidence suggesting 'that a shift from conflict management practices to critical forms of crisis transformation are required if the EU is to have a normative and legitimate foreign policy in conflict-affected societies around the world.'

Empirical analyses from the three case studies point to a significant gap between EU ambitions in favour of an emancipatory 'crisis transformation' approach stressing the need for providing attention to the individual and the local, and the structural courses of conflict, on the one hand, and a constrained and conservative practice of EU policy-making geared, especially in the EU's extended neighbourhood, towards EU's interests rather than norms and human rights, on the other hand. 
Following the breakdown of governance in parts of its neighbourhood in the 1990s, the EU has intervened by civilian, military or mixed CSDP missions in post-conflict areas. ${ }^{3}$ The EU has linked its foreign policy objectives to the Treaty of Lisbon (TEU/Art.21, 2) which among other goals comprises to 'preserve peace, prevent conflicts and strengthen international security' and to 'foster the sustainable economic, social and environmental development of developing countries, with the primary aim of eradicating poverty' (European Union HR/VP, 2016: 14f). In this regard, SSR has been the preferred mode of intervention for the EU in crisis areas as it has been seen as a cornerstone of liberal state- and peacebuilding processes and a concept at the conjunction of security and development. These two dominant threads of EU foreign policy are envisaged to integrate development assistance into security-related fields (Sedra, 2013: 371).

Core challenges for EU crisis response policy in Afghanistan, Iraq and Mali were structurally similar concerning (a) governance deficits, (b) ethnic, religious, social and economic fragmentation, (c) embeddedness in regional instability and power struggles, combined with poorly managed borders and cross-border interventions, rendering all these cases 'areas of limited statehood' (Krasner and Risse, 2014: 548). However, pronounced differences across cases exist regarding individual histories (including colonial), political cultures, and the various legacies of war involving external powers. Moreover, the EU's operational environment is complex not least because of multiple simultaneous international interventions within each of our cases demanding international coordination. The United States has been the agenda-setter as much as the international gatekeeper in Afghanistan and Iraq. Organisations like ECOWAS and the G5 Sahel play a much bigger role in Mali than regional counterparts do in Iraq and Afghanistan. The UN has been a key actor across the three cases with its own country or regional missions as much as regarding UN Security Council mandates providing international legitimacy for military and civilian engagement.

EU SSR has followed a similar pattern in different conflict settings - one size fits all (Börzel and Risse, 2004): The end or pause of major hostilities is followed by the design of liberal reform programmes in Brussels and EU member states' capitals based on good governance principles. Our three cases, although varying in detail, 
were or are located in conflict and post-conflict contexts (Hänggi, 2004: 17). In each case, the fragmentation of security structures has been particularly challenging, leading to similar policies in response to the respective crises. This matters when it comes to initiating and conducting missions and other policies, raising questions of neocolonialism (Nicolaïdis et al., 2015) or 'soft imperialism' (Hettne and Söderbaum, 2005). Britain in Afghanistan and Iraq, and France in Mali acquired special roles in the respective countries and acted de facto as 'lead nations' inside the EU's policy-making machinery. However, the role and motivation of key member states have been varying across cases and over time. The EU Council as well as EC crisis response policies, have been marked by structurally similar problem definitions leading to the same strategic and operational objectives, grand and operational strategies as well as the application of common tools and funding instruments (Peters et al., 2018: annex 6).

The research questions stated at the outset will guide and structure this analysis by utilising for the evaluation of policy effectiveness the standardised foreign policy cycle (output, outcome and impact effectiveness) (Peters, 2016: 27f, and Figure 2.1, this volume) focusing on respective CSDP missions. For assessing the characteristics of EU peacebuilding, the typology of conflict response will be used, differentiating conflict management, conflict resolution, and conflict transformation, or critical conflict

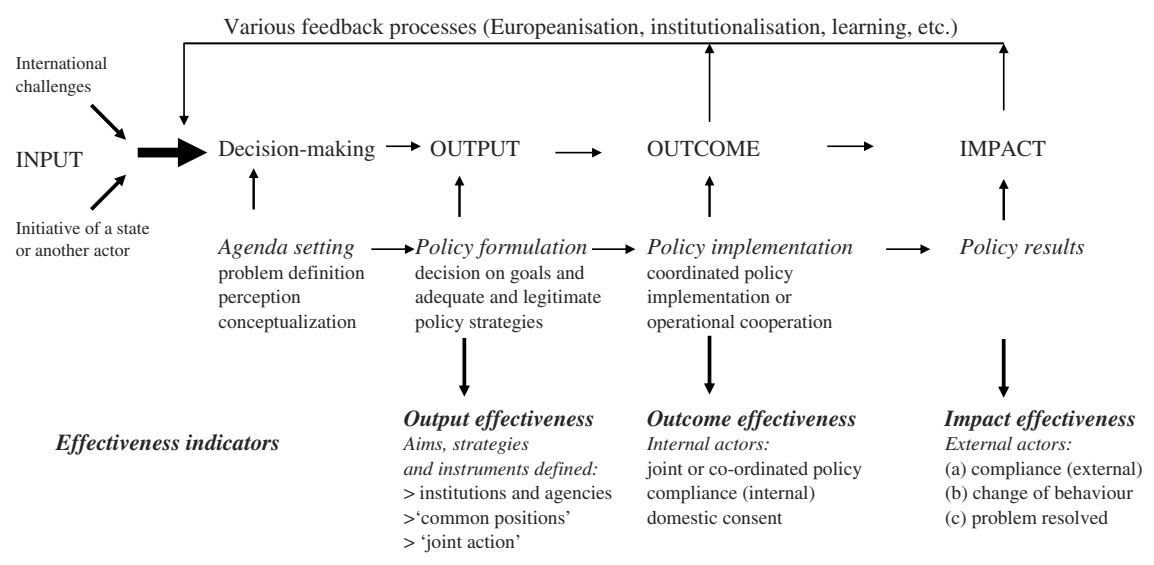

Figure 7.1: Categorising effectiveness: the example of CFSP

Source: Heider et al., 2004; based on Underdal, 2004. 
transformation (Table 7.1). ${ }^{4}$ Policy assessment is based on document analysis, background talks with actors of EU institutions and missions, public perceptions studies conducted in the framework of the EUNPACK project on-site, and implementation reports by the EU and experts' assessments. The EUNPACK perception surveys ${ }^{5}$ covered the EU's beneficiaries in the case countries, coupled with key informant interviews from each case (Echavez and Suroush, 2017; Mohammed et al., 2017; Cissé et al., 2017). Additionally, key stakeholders from the Brussels institutions were interviewed. ${ }^{6}$

\section{Effectiveness of the EU's crisis response policy in Afghanistan, Iraq, and Mali: evaluating the EU's crisis response output and outcome effectiveness}

\section{Effectiveness as actor coherence}

Actor coherence, measured as actor unity (of voice) $)^{7}$ on the output level and evolution of mandates on the outcome level, posed a major challenge for the EU in Afghanistan and Iraq while in Mali the challenges emerged primarily with policy implementation (policy outcome). In general, horizontal as well as vertical coherence was hampered by diverging member states' preferences. The often slowly emerging consensus and compromises among member states regarding strategic decisions in the EU Council in the early years of policy formulation for Afghanistan and Iraq retarded opportunities for Commission engagement, that is statebuilding via reforming and building pertinent (state) institutions (Burke, 2009: 8; Peters et al., 2018: 12).

Actor unity on the output level is an indispensable precondition for any mission mandate. In the case of Afghanistan, the sluggish increase in EU mission staff and operationally limiting budgets resulted in the harmonisation of EU engagement only by 2012 . Moreover, member states' bilateral policies in the realm of SSR, such as the German Police Project Team (GPPT), the Italian carabinieri regiment seconded to the NATO Training MissionAfghanistan (NTM-A) or the UK's close-hold operations in Herat were not harmonised. Coordination with and between member states remained difficult within the International Police Coordination 
Table 7.1 Classification of peacebuilding frameworks

\begin{tabular}{|c|c|c|c|c|}
\hline & $\begin{array}{l}\text { Hyper-conservative } \\
\text { (political realism, } \\
\text { top-down) }\end{array}$ & $\begin{array}{l}\text { Conservative } \\
\text { (top-down and bottom-up) }\end{array}$ & $\begin{array}{l}\text { Orthodox } \\
\text { (multilevel approach) }\end{array}$ & Emancipatory \\
\hline Generation & First generation & First and second generation & Third generation & Fourth generation \\
\hline Type & $\begin{array}{l}\text { Crisis(Conflict) } \\
\text { Management }\end{array}$ & Crisis(Conflict) Resolution & $\begin{array}{l}\text { Crisis(Conflict) } \\
\text { Transformation }\end{array}$ & $\begin{array}{l}\text { Critical Crisis(Conflict) } \\
\text { Transformation }\end{array}$ \\
\hline \multicolumn{5}{|c|}{ Characteristics } \\
\hline Premises & $\begin{array}{l}\text { Conflicts are endemic to } \\
\text { men; external actors as } \\
\text { balancer. } \\
\text { Meta-level: } \\
\text { >>rational application of } \\
\text { scientific knowledge } \\
\text { >>order through interna- } \\
\text { tional cooperation over } \\
\text { coercion }\end{array}$ & $\begin{array}{l}\text { Crystallised out of a critique of } \\
\text { conflict management. } \\
\text { >>Conflict as psychological, } \\
\text { sociobiological or product of } \\
\text { political, economic and social } \\
\text { structures } \\
\text { >>Conflict arises out of repression } \\
\text { and deprivation of human needs } \\
\text { which is a social and a psychological } \\
\text { phenomenon }\end{array}$ & $\begin{array}{l}\text { Lies at the heart of the } \\
\text { liberal peacebuilding } \\
\text { project. } \\
\text { >> Emphasizes require- } \\
\text { ments and perceptions of } \\
\text { policymakers, officials and } \\
\text { actors involved in top-down } \\
\text { and bottom-up visions of } \\
\text { peace at first with local } \\
\text { actors' consent and later } \\
\text { also without. }\end{array}$ & $\begin{array}{l}\text { Crisis Resolution and } \\
\text { Transformation created } \\
\text { conditionality between the } \\
\text { agents and recipients. } \\
\text { >>Pluralist, critical and } \\
\text { self-reflective approach } \\
\text { (all of society) }\end{array}$ \\
\hline
\end{tabular}


Table 7.1 (continued)

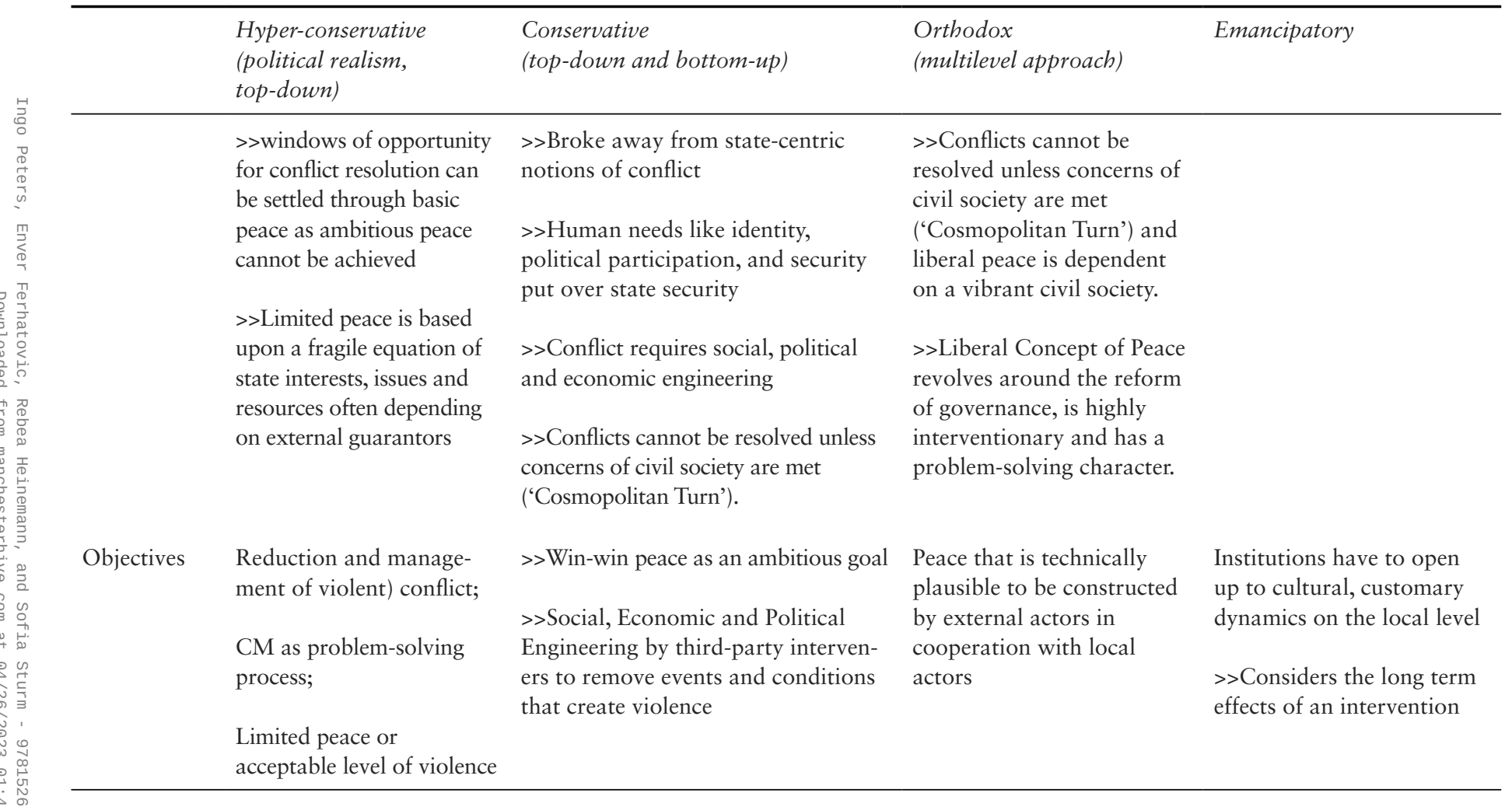


Table 7.1 (continued)

\begin{tabular}{|c|c|c|c|c|}
\hline & $\begin{array}{l}\text { Hyper-conservative } \\
\text { (political realism, } \\
\text { top-down) }\end{array}$ & $\begin{array}{l}\text { Conservative } \\
\text { (top-down and bottom-up) }\end{array}$ & $\begin{array}{l}\text { Orthodox } \\
\text { (multilevel approach) }\end{array}$ & Emancipatory \\
\hline Policy tools & $\begin{array}{l}\text { Mediation, coercion, } \\
\text { robust peacekeeping; } \\
\text { military intervention }\end{array}$ & $\begin{array}{l}\text { Multi-track diplomacy, peacebuild- } \\
\text { ing and contingency approaches }\end{array}$ & $\begin{array}{l}\text { Multiple forms of interven- } \\
\text { tion: UN peace operations, } \\
\text { mediation and negotiation, } \\
\text { development, humanitarian } \\
\text { relief and specialised reform } \\
\text { of security, economy, } \\
\text { borders, HR and RoL }\end{array}$ & $\begin{array}{l}\text { Mediation between the } \\
\text { local and international over } \\
\text { peacebuilding practice and } \\
\text { social, political and } \\
\text { economic practices that } \\
\text { both deem acceptable. } \\
\text { >> Review and monitoring } \\
\text { of measures }\end{array}$ \\
\hline $\begin{array}{l}\text { External } \\
\text { agents }\end{array}$ & $\begin{array}{l}\text { States, Individuals, } \\
\text { institutions and IOs - as } \\
\text { external guarantors }\end{array}$ & $\begin{array}{l}\text { Peacekeepers, NGOs, donors and } \\
\text { officials }\end{array}$ & $\begin{array}{l}\text { International actors, UN, } \\
\text { IFIs, NGOs }\end{array}$ & $\begin{array}{l}\text { Regional and International } \\
\text { actors }\end{array}$ \\
\hline $\begin{array}{l}\text { Agents } \\
\text { addressed; } \\
\text { addressees }\end{array}$ & $\begin{array}{l}\text { State actors and political } \\
\text { elites }\end{array}$ & $\begin{array}{l}\text { Local (individual and civil society), } \\
\text { state actors }\end{array}$ & $\begin{array}{l}\text { Local, state and regional } \\
\text { actors }\end{array}$ & $\begin{array}{l}\text { Non-elite actors from the } \\
\text { ground/bottom level }\end{array}$ \\
\hline
\end{tabular}

Source: Peters et al., 2018; based on Richmond et al., 2016. 
Board (IPCB) and the Law and Order Trust Fund for Afghanistan (LOTFA) due to diverging national approaches (European Court of Auditors 2015: 15-17). In the case of Iraq, after the US-led war in 2003, a profound split between the war-opposing and warsupporting member states preceded and significantly influenced the EU internal decision-making processes regarding EU engagement in general and the deployment of a CSDP rule of law mission in particular (Council of the European Union, 2012: 3; 2016: 3f). For example, initiatives for creating the post of an EU special envoy or representative to Iraq and opening an EU office in Baghdad were temporarily blocked not least by France, since Paris confined institution-building in Iraq to the UN (Youngs, 2004: 8). In contrast, the EU engagement in Mali was from the very beginning characterised by a largely unitary and swift reaction in the face of the unfolding crises (Council of the European Union, 2012a: 5; Council of the European Union, 2012b: 3).

Regarding actor coherence on the policy output level in response to lessons learned during policy implementation, evolving mandates were a feature of EU crisis response policy across cases. ${ }^{8} \mathrm{~A}$ chief example of changing contexts and adjustment of policy priorities was the shift of EU concerns towards containing migration which gradually emerged following the 'Arab Spring' of 2011. The inclusion of migration also in Council documents indicates a shift towards securitisation of the migration issue (in terms of perceiving it a security threat rather than a humanitarian challenge) and signifies a strong nexus between the EU's and its member states' internal and external policy agenda. This shift was also observable concerning the EU's neighbourhood - for example, in Libya (Council of the European Union, 2015). CSDP missions' mandates were changed in Afghanistan four times in nine years (2007-16), in Iraq twice in eight years (2005-13), and in Mali three times in seven years (2013-20). The evolution of mandates, however, also illustrates the EU's ability to find a common response to changing contexts. In Afghanistan, for example, the mission's initial focus on capacitybuilding (mentoring and training) was progressively replaced by an advisory approach. In Mali, with its third mandate, the EUTM broadened its narrow focus from training and advice towards, inter alia, a geographical extension and the intensification of regional cooperation with the G5 Sahel (Council of the European Union, 
2016: 3f). In consequence, the EU policy-making on the output level of policy rhetoric and ambitions has de facto been meandering between the crisis response types of conflict resolution, conflict transformation and critical conflict transformation.

\section{Effectiveness as process coherence}

Besides actor coherence, process coherence impacts effectiveness of EU policies in terms of changing actors' behaviour and resolving political problems defined at the outset. The criteria for assessing process coherence encompass coherence of policy features, institutional coherence, continuity of core concepts (Peters et al., 2018: annex 7) and resonance of EU output with implementation (equipment, personnel, training, monitoring). Concerning the first criterion, the core strategic, as well as intermediate objectives of the $\mathrm{EU}$, have been continuously visible in EU policy formulation. EU strategic objectives in essence covered improving 'security', 'stability' and 'prosperity'. ${ }^{9}$ On the operational level, problem definitions, objectives and strategies, as indicated in mission mandates and other core EU documents displayed a high degree of continuity and visibility, indicating policy output effectiveness. Operational strategies (transformative mechanisms) like socialisation (by dialogue and partnership) and capacity-building (by empowering state institutions, personnel and civil society) are well embedded in EU 'grand strategies'. Good governance norms like democracy, human rights and rule of law have been guiding mandate formulations across the cases, resembling dominantly the third generation of crisis response policy that is crisis transformation.

When it comes to institutional coherence - across EU institutions, between EU institutions and member states, in Brussels as well as in the field - empirical evidence points at discontinuity of horizontal and vertical coherence. For example, the lack of prioritisation and coordination of policies between the Commission and EUPOL-Afghanistan rendered capacity-building efforts like training and the oversight function within LOTFA and the IPCB ineffective (European Court of Auditors, 2015: 18f, 30f). Although the Multiannual Indicative Programme states that 'the EU can build on the groundwork established by the CSDP Mission (EUPOL Afghanistan)' (European Commission and EEAS, 2014: 8), the 
'proposed result indicators were not related to EUPOL's civilian policing outcomes' (European Court of Auditors, 2015: 30). Thus, the institutional coherence in the field remained a challenge, as the EU Delegation/EUSR had no clear objectives beyond support for the Trust Fund, while the member states' policies and CSDP Mission lacked coordination and sustainable long-term planning (European Court of Auditors, 2015: 18). In Mali, coordination of policies between the EEAS and the Commission remained challenging. To add to the complexity at hand with the latest European Defence Fund (EDF) review, the Commission identified security as a priority concern, marking a departure for an institution primarily responsible for development. ${ }^{10}$

EU crisis management policy across our three cases has been shaped by intergovernmental policy-making with national approaches often diverging also during policy implementation. In Afghanistan, the lack of coordination between the member states, EUPOL, the EUSR and the EC was detrimental to the SSR efforts. Yet, an agreement to jointly set up the Professional Training Board for the development and accreditation of police training curricula was accomplished (European Court of Auditors, 2015: 19). In the Iraq case, the empirical investigation of EU documents also revealed issues with policy and institutional coherence for the implementation of the EUJUST LEX mandate. During Javier Solana's term, tensions reportedly existed between the role of the HR/VP and the Political and Security Committee (PSC) regarding coordination with other key players (Korski, 2010: 236). As indicated by background talks, coordination between EUTM Mali and other EU instruments has reportedly worked well on the ground. ${ }^{11}$

However, insufficient external EU cooperation and coordination (or competition) with domestic authorities and international actors was detrimental across all three cases. In Iraq, for example, the gradual increase of the EU Commission's assistance for reconstruction and development rendered coordination with the UN and the World Bank indispensable, which both acquired through a growing role in the Donor Committee of the International Reconstruction Fund Facility for Iraq (IRFFI). The EU Commission's dissatisfaction with the IRFFI performance due to its technical approach led to policy adjustments when the EU shifted funds directly towards civil society groups (Youngs, 2004: 12f). In Mali, Malian government 
representatives complained that international partners follow their agenda without consulting domestic authorities' which leads to accusations of international tutelage or loss of national sovereignty (Tull, 2017). Cooperation with ECOWAS and the UN has been considered crucial for an effective training mission.

Effective policy implementation is about the resonance of EU policy output with policy practice. In all three cases, shortages of material and equipment due to slow procurement and limited budgets curtailed the quality of the training and operational readiness (Council of the European Union, 2013: 5; Barea, 2013). EUPOLAfghanistan throughout its lifecycle had problems with the procurement of equipment for the mission (European Court of Auditors, 2015: 46). In Mali, a lack of communication equipment prevented FAMa from protecting the population in the north (Bøås et al., 2018: 17; EEAS, 2015: 4, 9).

Similar problems marked our three cases regarding mission personnel. Pledges made in terms of staff deployment were mostly not followed up in practice, thus undermining the legitimacy and effectiveness of the missions. In Afghanistan, EUPOL's impact was limited partly due to low levels of staff seconded by the EU member states. The mission strength authorised was 400 staff, but never exceeded 340 (in 2012) (European Court of Auditors, 2015: 12f). For EUJUST LEX - implemented mostly outside Iraq until 2009 merely four staff members were deployed inside Iraq (Korski, 2010: 237). Only with the amended mandate of 2009 , the number of staff in Baghdad rose to eight in 2010 and ultimately 66 (including 13 locals and $40 \%$ female) until the end of the mission in December 2013 (EEAS, 2014a). With over 580 personnel by 2016, EUTM Mali is a relatively big mission. However, compared to a mission strength of 4,000 French personnel deployed in the context of its military intervention force Opération Barkhane in the Sahel, the relevance of EU numbers is modest and its possible impact may be questionable (EEAS, 2016: 2).

CSDP capacity-building has been implemented through advising, mentoring, monitoring and training of relevant ministries' personnel, police officers, judiciary, prison services and military personnel. These policy features convey a governance-focused approach targeting key state actors and resemble a hybrid between conflict resolution and conflict transformation. Across cases, the EU missions 
delivered notable results, although to varying degrees. In Afghanistan, capacity-building was implemented through the establishment of the Police Staff College, the Criminal Investigation College and train-the-trainer courses. Moreover, civilian norms were promoted through institutional capacity-building inside the Ministries of Interior and Justice and the Attorney General's Office. However, incoherence existed regarding understandings of civilian policing, mostly rooted in the diversity of EU security cultures and practices, and quality of EU personnel. EUPOL learned at an early stage that it was crucial to agree on a mission-wide common understanding as incoming experts often expected to convey their ideas known from their home countries. ${ }^{12}$ Similarly in Iraq, member states failed to implement one of the key recommendations of the Iraq Expert Team: 'to develop a common and detailed curriculum that all the training had to follow' (Korski, 2010: 238).

Another indicator of the crisis transformation approach focusing on key governance institutions, is the EU engagement in building up local Civil Justice Systems, police and military. In all three cases the EU did not foresee a critical evidence-based evaluation of mandate implementation, quality assurance and objective monitoring of mandate implementation. This can be explained mostly due to security concerns, risk aversion and lack of deployed resources but ultimately the lack of delivery by EU member states. In Afghanistan, due to the security constraints, monitoring of trained police was never an option. For Iraq, lessons learned could only partially be developed due to security restrictions on travel. Hence, evaluation seminars happened, but until 2010/11, the effectiveness of the training could not systematically be assessed. ${ }^{13}$ Additionally, political constraints undermined the EU's ability to deliver. For instance, the EU did not get access to Iraqi training establishments (Christova, 2013: 435) while in Mali, training an army at war but not monitoring and tracking the trained soldiers due to security reasons limited the possibilities for follow-up training.

The fourth criterion for process coherence is continuity of core concepts marking EU policy output and outcome, primarily meaning the comprehensive approach, conflict sensitivity, and local ownership. The comprehensive approach ${ }^{14}$ is inherent in the policy features identified as 'grand strategies' of EU crisis response documents. The high aspirations formulated on the level of general 
objectives by respective operational strategies and mission mandates suffered significantly from the changing security situation on the ground in Afghanistan and Iraq during policy implementation.

In Afghanistan, the application of the comprehensive approach was problematic due to the deteriorating security situation on the ground, and the lack of SSR expertise within the EU Delegation/ EUSR. In Iraq, EU Commission policies became re-oriented from an 'agenda for change' to an 'agenda for consolidating'. This de facto entailed a farewell to the ambitions of a comprehensive approach in favour of pragmatic adjustments resembling conflict resolution at best despite more ambitious rhetoric; simultaneously, this corresponded with the end of the EUJUST-LEX Iraq mission in December 2013 (European Commission, 2014: 6-12, n52). Commission problem definitions for Mali have been witnessing a gradual shift towards stability and security, which was manifest in the EU's approach to MENA countries after the Arab Spring of 2011 and the respective EUNPACK case study on Libya. With this shift, a strong security-development nexus became emphasised also indicating the EU's ambitions towards a comprehensive approach (European Commission, 2015). As in Afghanistan, there was however a mismatch between the skills of EU delegation staff with development backgrounds on the one side and the security expertise needed when collaborating with the Ministry of Interior and Police on the other side (Bøås et al., 2018: 17).

The concept of conflict sensitivity ${ }^{15}$ based on the 'do-no-harm' approach has consistently been part of pertinent documents on EU crisis response, signifying a critical conflict transformation approach. However, the actual continuity and visibility of the concept have increased over time, with most references in policy documents regarding Mali (Peters, 2017: annex 3). This evolution of reference to the concept shows its increasing significance for policymaking and its relevance for policy implementation. However, in the daily work of EU practitioners, the concept of conflict sensitivity tends to be merely sullenly accepted. ${ }^{16}$ In general, EU normative principles of crisis response policy match the EU's identity. On the ground the lack of conflict sensitivity has led to civilian policing standards being prioritised within an open conflict setting in Afghanistan. In Iraq, conflict sensitivity was insufficient concerning the EU's awareness and equal treatment of minority groups (Bapir, 2010). Furthermore, a proper understanding of the legal systems of 
the countries of concern was missing (Korski, 2010: 237). In Mali, the EU has not acted in conflict-sensitive ways when training an army that does not include all ethnicities, has low legitimacy among the Malian population and supports a partly illegitimate state (Bøås et al., 2018: 15). Hence, the EU supports structures that are root causes for the conflict in Mali and might therefore even increase the prevalent fragmentation in the society. Another challenge for a conflict-sensitive EU engagement in any unstable country is being caught in the 'counter-insurgency logic' (Vermeij, 2015: 3): The focused support for primarily central government actors to enhance stability remains an ambiguous practice, typical for conflict management practices (as opposed to the concepts of conflict resolution or transformation) since it leads to preserving the conflict-prone status quo.

The EU's performance concerning local ownership ${ }^{17}$ has been identified as one of the pertinent features of the EU crisis response on the level of policy formulation and implementation, signifying the concept of conflict transformation. Of all EU normative premises, the concept of local ownership appeared most often across EU policy documents concerning our three cases (Peters et al., 2018: annex 3). In practical terms, in Afghanistan, for example, mainstreaming human rights in training modules, and developing a female policing component within the ANP ran counter to Afghan priorities. In Iraq, the mission was responsive to local concerns by continuous amendments of course curricula and design. Likewise, the incorporation of 'Work Experience Secondments' as an element of EU police training occurred reportedly 'in response to the Iraqi request for more practical learning experiences' (Dari et al., 2012: 56; Troszczynska-van Genderen, 2010: 19). In Mali, domestic stakeholders criticised that the European trainers and experts delivered courses too abstract for daily practice, indicating a lack of knowledge of the reality on the ground (Bøås et al., 2018). The Malian government further laments shortages in weaponry and an overall tactical approach of EUTM training procedures, while the EUTM mandate explicitly stresses the non-combat character of the mission (Malijet, 2017; Skeppström et al., 2015: 357). This example illustrates, far more than only a material deficiency, a political mismatch between Malian authorities and the EU. ${ }^{18}$ Policy responsiveness to changing circumstances as much as to priorities identified by domestic authorities hence link conflict sensitivity and local 
ownership, and so EU ambitions were translated into political practice, but more in terms of managing the conflict then transforming it.

\section{Evaluating the EU's crisis response impact effectiveness}

Ultimately, the EU's crisis response policy aims at 'making a difference' that is changing actors' behaviour and solving problems on the ground according to the EU's definitions of issues and inferred policy objectives. This dominantly leads to a rhetoric of the third generation of crisis response policy that aims at conflict transformation, while EU policy practice remained at best in the realm of conflict resolution if not crisis management. Therefore, the impact effectiveness of the three CSDP missions is measured against the respective mandates and concerning, first, EU strategic and intermediate objectives, second, EU operational objectives, and third, the core policy concept of local ownership based on domestic perceptions of EU policy-making. This evaluation is indicating overall policy features and causal factors regarding EU crisis response policy at large (Bøås and Rieker, 2019).

In sum, the EU's ambitious programmatic statements (Peters et al., 2018: annex 6) on its (a) strategic objectives to contribute to peace, security, sustainability, prosperity, peace and stability, (b) intermediate aims of democratisation, internationalisation, statebuilding and promotion of human rights/gender, and (c) operational objectives to contribute to the establishment of effective civilian policing in Afghanistan, to strengthen the rule of law and promote human rights in Iraq and to strengthen and contribute to the restoration of military capacity to restore Malian territorial integrity, were coherent regarding policy formulation but lacked local ownership and legitimacy. Once more, the EU's emancipatory ambitions became visible but were not matched by its policy implementation.

\section{Impact of EU policy: strategic and intermediate objectives}

Our three cases from the extended neighbourhood have been beset by similar challenges of weak statehood preceding EU engagement. 
Hence, progress made regarding EU objectives of supporting peace, stability and prosperity and good governance in Afghanistan, Iraq and Mali may become discernible by pertinent indices. ${ }^{19}$ In Afghanistan, support to the MoI, the ANP and judicial authorities focused on key institution-building elements. The Democracy Index score for Afghanistan has even slightly deteriorated from 3.06 in 2006 to 2.85 in 2019, though with an upward trend over the past three years (The Economist Intelligence Unit, 2019: 13). However, the Worldwide Governance Indicators show a positive tendency, ${ }^{20}$ and the Corruption Perception Index has considerably improved from 1.8 in 2007 to 15 in 2017, though this rank is still one of the lowest (177 out of 180) (Transparency International, 2018).

Iraq has been categorised as a 'chronically fragile state' since 2008 (OECD, 2018: 26), and the perceived level of public sector corruption remained high during the mission. Currently, Iraq still ranks 169 out of 180 countries (Transparency International, 2018). Similarly, the Democracy Index score stuck around 4 (on a scale of 0 to 10) (The Economist Intelligence Unit 2018: 16). Although Mali's governance has improved since the crisis in 2012, ${ }^{21}$ the scores are lagging behind those before the crisis and it has lost its status as one of the few at least 'flawed democracies' in sub-Saharan Africa (The Economist Intelligence Unit, 2017). Mali has remained 'extremely fragile' since 2014 and continues to perform poorly regarding security and corruption indicators (OECD, 2018: 86).

Human Rights and Gender are, according to EU policy premises, falling somewhere between the concepts of conflict transformation and critical conflict transformation, mainstreamed throughout SSR activities in the three cases. However, such a policy remains controversial since all case countries are marked by diverse religious and ethnic communities with traditions not resonating with Western normative standards. In Afghanistan, EU commitment in protecting human rights and gender was mirrored in extensive training of the Afghan police to respect human rights as a key element of EUPOL engagement. Yet, allegations that 'the national police has been responsible for incommunicado detention, enforced disappearances, mass arbitrary detention and extrajudicial killings during counter-insurgency operations' (UN, 2017: 4) persisted. According to EU self-assessment, EUJUST LEX accomplished significant improvements regarding prison management, prison security and 
prisoners' human rights as well as local capacities for fighting domestic violence and trafficking in persons (EEAS, 2014b). However, the Commission at a later stage concluded more critically that Iraq still lacked a stable system of rule of law, as demonstrated by human rights violations against civilians committed by Iraqi Security Forces and affiliated armed groups in their efforts to defeat ISIL (European Commission, 2014: 7; UN, 2015). EUTM Mali has provided training to all ranks in the Malian military forces, including courses on the humanitarian situation, human rights, protection of women, children and displaced persons and the return of refugees (Carrasco et al., 2016). Nevertheless, severe human rights violations by Malian military counter-terrorism operations as well as sexual and gender-based violence committed by members of the military in conflict-affected areas were reported (Human Rights Watch, 2017; UN, 2016).

In sum, the impact effectiveness of EU efforts on the level of strategic and intermediate objectives across cases are overshadowed by poor results when looking at general governance indices and pertinent human rights reports. Causally, this can be ascribed to the EU's focus, despite its more ambitious policy objectives, on narrow security concerns and stabilisation strategies rather than addressing underlying structural issues thus resembling conflict resolution or at best conflict transformation, but hardly critical conflict transformation (see EU crisis response paradoxes 4 and 5 in Bøås and Rieker, 2019: 15-16).

\section{Impact of EU policy: operational objectives}

On the operational level, capacity-building refers to the training of respective police (Afghanistan and Iraq) and armed forces (Mali) as well as institutional reforms contributing to political stability in the respective country overwhelmingly reflecting a statist model of conflict resolution.

By 2016, approximately 7,300 Afghan police officers had attended the various higher education courses offered by the Police Staff College facilitated by EUPOL-Afghanistan. The mission moreover supported the build-up of the Female Police within the ANP starting with 180 in 2007 to reach 3,200 by 2016 (Suroush and Ferhatovic, 2017: 16). After seven years, according to official EU 
figures and self-assessment, 5,000 Iraqi Criminal Justice System (CJS) personnel and more than 7,000 Iraqi officials were trained (EEAS, 2014b). However, concerning the overall number of police (about 400,000), the possible impact of EU efforts remained modest at best (Christova, 2013: 427). In Afghanistan, the high attrition rates of up to 75 per cent in 2011 (House of Lords, 2011: 19) and lack of monitoring in the field limited the impact of training. Moreover, CJS personnel faced violent attacks and suffered significant losses between 2003 and 2011, with figures varying from 9,000 to 12,000 (Christova, 2013: 430; Korski, 2010: 238). The EU's post-training monitoring data was limited on 'how many of the course-goers are alive, remain in their jobs or have been promoted, let alone whether they are applying their skills' (Korski, 2010: 239). As of July 2018, EUTM Mali trained 12,000 FAMa trainees in total (EUTM, 2018). Even taken at the highest estimation of the total number of Malian security forces (estimated numbers to 20,000), 22 EUTM Mali has trained a remarkable number of soldiers in five years, and hence accomplished its operational goal to contribute to the restoration of FAMa's military capacity. However, the education and training level of Malian soldiers within a course vary and therefore affect the effectiveness of training by EUTM Mali (Fuhrmann, 2016).

In sum, concerning the overall number of police in Iraq and Afghanistan, the dominance of the NTM-A, the United States/ United Kingdom in Iraq and France in Mali, the possible impact of EU efforts unavoidably remained modest at best. These achievements on the operational level sound impressive, however, high numbers do not reflect the qualitative standards of police or military training. Moreover, the significance of these numbers is questionable given the lack of EU's engagement with underlying structural issues and root causes of the conflict resulting in conflict transformation at best (see paradox 4 in Bøås and Rieker, 2019: 15).

\section{Impact of EU policy: local ownership}

In its documents and policy statements, the EU has persistently conveyed its ambitions to facilitate social and political reforms but not to impose its policy preferences on the partner country. In 
consequence, local ownership has continuously been a declared intermediate goal to empower the people and the country to take care of its concerns autonomously and hence to foster the legitimacy and sustainability of EU policies. From an EU perspective, 'ownership' basically refers to recipient countries and actors sharing or embracing EU premises concerning SSR, including basic policy norms of good governance. This chapter analyses ownership along its inherently relational dimension, taking into account that EU priorities are often diverging or difficult-to-align with local understandings and practices, hence laying bare once more the mismatch between conflict-transformation action and critical conflict-transformation rhetoric.

In Afghanistan, local ownership was a key principle within EUPOL's stated objectives and strategies to contribute to the establishment of sustainable and effective civilian policing arrangements (Council of the European Union, 2007). However, ownership and conflict sensitivity have not always been tangible, as Islamic law and native customs were not covered by training curricula (European Court of Auditors, 2015: 25). According to EU self-assessment, EUJUST LEX-Iraq had excellent relations with both domestic and international counterparts, and Iraqi experts participated in the design of curricula for training courses. Still, it remained uncertain whether EU training practice was adopted by the Iraqi police's training plan. Besides, EU police professionals allegedly did not grasp the specifics of Iraq's political system in general and the legal system in particular (Korski, 2010: 238). EUTM Mali's regionalisation efforts, by extending its training to the G5 Sahel Joint Force, could be an avenue towards a 'long-desired Africanization of international efforts' (Lebovich, 2017), with the G5 Joint Force representing another level of the 'local'. Moreover, favouring one regional actor (G5) instead of or even at the expense of another (ECOWAS) could trigger (unintended) consequences in terms of conflict sensitivity (Lebovich, 2017).

As a complement to ownership, the respective perceptions of EU conflict and crisis engagement by conflict-affected societies and international actors matter if taking the premise of critical conflict transformation as a prerequisite for legitimate and effective crisis response policy seriously. In practice, lack of local ownership tends to impair the EU's legitimacy and lead to unsustainable policies. 
The focus of the EUPOL mission on civilian policing was criticised by the Afghan MOI as well as by major international actors like the US and NATO Training Mission between 2009 and 2011 (Bayer Tygesen, 2013). NTM-A's dominance of the international training effort, its focus on fighting the insurgency coupled with the lack of civilian police trainers led to poorly-trained police, which in consequence was seen as 'corrupt, brutal and predatory ... [and] ... feared and mistrusted' by Afghan citizens. ${ }^{23}$ 'The EU approach to rolling out a civilian police training programme and it's subsequent failure to gain the support of the local stakeholders fighting the insurgency thus served to symbolize its ineffectiveness' (House of Lords, 2011: $3)$. The lack of involvement of Afghan police officials in the implementation of the EUPOL Operational Plan further hampered local buy-in (Suroush and Ferhatovic, 2017: 19).

Perception studies conducted within the EUNPACK project show that a general sense of awareness about international actors involved in crisis response could be detected. Specific knowledge of EUPOL engagement among local communities was lacking with over half of the respondents of communities with EUPOL-trained staff not being aware of the mission. Even more, among those aware of EU crisis response, respondents said either they had a neutral attitude regarding their satisfaction with EU support or criticised that it would disproportionately benefit EU officials, state officials and the military while it would not extend to the marginalised parts of communities (Echavez and Suroush, 2017: 8f).

In Iraq, successive governments evaluated EUJUST LEX primarily as a political symbol for Europe's overall Iraq engagement. EUNPACK perception studies (Mohammed et al., 2017: 3) indicate, however, that the majority of interviewed domestic actors are aware of the EU's engagement in crisis response in Iraq albeit a comparatively low awareness became tangible regarding specific CSDP activities, while the awareness of other EU-funded agencies and projects (UNDP, NGOs) and international actors (UN, US) was remarkably higher. The highest number of respondents, $87.5 \%$, was aware of the EU's engagement in the humanitarian field and the second-highest number, $77 \%$, was reported in the capacity development field (Mohammed et al., 2017: 3). While the overall attitude of participants towards EU crisis response engagement in Iraq received a considerable positive score (39\% partially satisfied, $30 \%$ 
satisfied), the EU assistance was considered 'well-targeted' (75\%) and of the 'right type' (70\%) (Mohammed et al., 2017: 6).

Training courses by EUTM Mali have been perceived as too short or concepts being too abstract for the local reality (Djiré et al., 2017: 42). Furthermore, the lack of knowledge about the content of EU engagement among the Malian population indicates a lack of effort to achieve ownership through a proper communication strategy by the EU. And yet, respondents in Bamako - to which interviews were confined - still had a rather positive view of the EU being conflict-sensitive $(58 \%)$ and helping to mitigate the crisis (72\%) (Cissé et al., 2017).

In sum, our findings support the overall results of the EUNPACK project regarding those paradoxes flagging ownership issues. EU interventions display across the three cases a tendency of lacking thorough understandings of root causes of the conflicts they try to tackle as much as the often visible mismatch of EU and local populations preferences (see paradoxes 1-3 in Bøås and Rieker, 2019: 15).

\section{Conclusions: the politics of peacebuilding, SSR and CSDP missions}

In this concluding section, we focus on the most salient dimension of EU crisis response policies: the politics dimension of EU efforts. It covers $^{24}$ collective preference formation and decision-making across policy-making in and between the member states, between member states and EU institutions, between and inside EU institutions, among different representations of the EU on-site, as well as between the EU and domestic actors ('locals').

\section{The politics dimension on the intergovernmental level}

Crisis response policy is more than formulating and implementing functionally appropriate strategies - 'it is politics, stupid!', regarding preferences of member states and the challenge of reaching viable compromises. Interestingly, though not surprisingly because of the principal-agent relationship (Kassim and Menon, 2003; Hawkins et al., 2006), the EU policy is mostly turning a blind eye 
towards the politics of crisis response policy and instead focuses on coordination problems and institutional challenges of policymaking. Nevertheless, EU lessons-learned documents 'go political in disguise' when criticising an incoherent statebuilding strategy not systematically related to SSR. Likewise, the criticism of the projectbased approach for lacking flexibility due to its short-term nature, or the depreciation and lack of a long-term strategic approach and the limitation of measures on the operational/technical level ignoring governance as a cross-cutting issue are indeed political issues (European Commission and HR/VP, 2016: 11, 3; Bøås and Rieker, 2019: 11f).

EU lessons learned hence entail a tendency of de-politicisation, in terms of a functional understanding of underlying challenges, which often comes at the expense of a proper diagnosis and therapy for operational challenges identified. ${ }^{25}$ Likewise, this de-politicisation is fostered by the comprehensive approach, which insinuates that peacebuilding is foremost about 'functional' 'social engineering'. However, without political settlements among conflicting parties in any given state or society, 'functional' SSR policies will mostly be in vain, as - among others - the cases of Afghanistan and Iraq show (Mac Ginty, 2010).

Another political dimension is the 'securitisation' of peace- and statebuilding of EU missions and SSR efforts since these responses are conceived as efforts at fending off security risks if not threats. Domestic concerns about migration have drastically shifted policy concerns and preferences. This transformed conflict response policy from fostering reforms and good governance to enhancing stability and functioning state administrations able to cut 'migration flows' for EU-internal security concerns, possibly aggravating credibility and legitimacy deficits of EU foreign policy. ${ }^{26}$ This internal-external nexus comes with issues of governments' legitimacy inside the EU and member states. Domestic discourses and concerns thus shape foreign policy preferences adding another politics dimension to EU crisis response policy. However, when analysing strategies and tools matching to EU problem definitions, some pitfalls can be seen. For example, EUTM Mali has no capabilities when it comes to 'fighting' migration, which is currently on top of the EU member state problem definitions regarding Mali, thus EUTM as a mission cannot be expected to address this issue. ${ }^{27}$ Overall, de-politisation and 
securitisation identified as 'meta-features' of EU crisis response policy are parallel but contradictory policy features with securitisation indicating a strong politicisation tendency spilling over from one to the other policy field. ${ }^{28}$

Achieving actor unity among member states as much as across EU institutions is a major factor for successfully formulating a swift policy response to conflicts and crises - as a necessary but not sufficient precondition for policy effectiveness (Thomas, 2012). Converging or diverging preferences will ultimately define the coherence of both Council and Commission foreign policy. Our case studies show that the quality of compromises among EU institutions or member states does not just define the quality of policy output but also significantly effects the quality of common policy implementation. Partly diverging preferences represent manifest cooperation and coordination problems, which - according to institutionalist writings (Martin, 1993; Zürn, 1993) - may gradually be overcome by adjustments of institutional forms and practices.

Political leadership is one mechanism for facilitating intergovernmental foreign policy-making and EU SSR and CSDP missions - exemplified by, France's role as the 'lead nation' in Mali embedding its national engagement in EU crisis response policy (Janning, 2005). Colonial ties of EU member states may provide a comparative advantage concerning country and language expertise. However, this may render those member states more immediate stakeholders than the EU. This in turn may infringe on the EU's legitimacy via negative impact on 'local ownership' due to reservations regarding post/neo-colonial engagement. In consequence, an inherent tension exists between greater effectiveness due to political leadership by individual EU member states and the representation of the EU as a whole (Okemuo, 2013).

\section{The politics dimension on the institutional level}

The overlap of EU instruments and action leads to frequent misinterpretations in the field on the roles of EU Delegations and CSDP missions in regards to representation, reporting and donor coordination (European Court of Auditors, 2015: 18). The EU's institutional complexity implies 'political deals', a system of political 
checks and balances impeding effectiveness and efficiency of individual policies. Hence, 'turf wars' within CFSP, CSDP and SSR policies leading to delays and inefficiency are not just a coordination problem but are also about competencies, resources, relative influence and hierarchy inside the EU that is about lower-level politics. This also applies to other international actors, not least the UN, and even to state actors like the United States concerning its inter-agency policy coordination in the realm of conflict and crisis management. ${ }^{29}$ Hence, the aforementioned feature can hardly be ascribed to the sui generis character of the EU polity - at least not in principle (Øhrgaard, 2004). Mere coordination challenges based on political disagreements on policy goals and strategies - viewed again through the lenses of institutionalist research - could be overcome by respective institutional adjustments. In the cases of Afghanistan (after 2011) and Mali (early established through the EUSR in 2014), for example, coordination mechanisms under the auspices of the EUSR supported a comprehensive analysis of the crisis environment and enhanced policy coordination, which had a positive impact on the delivery of respective mandates.

\section{The politics dimension on the local level}

Guiding principles of EU foreign policy in general and conflict response policy in particular - like conflict sensitivity, local ownership and a comprehensive approach - have been continuous features of EU policy documents and practices across our three cases, hence underpinning the EU's critical conflict transformation ambitions. As deeply ingrained causal beliefs (George, 1979), these principles are constitutive for EU foreign policy. By emphasising its constitutive set of social and political norms and practices, the EU in the cases at hand promoted itself as a role model in terms of externalising its norms and 'institutions' to the cases in question (Schimmelfennig and Sedelmeier, 2005; Bøås and Rieker, 2019: 11-15). However, these identity-related causal beliefs are highly political for establishing the EU as an international actor on the global level.

Hence, a final dimension of politics regards the very motivation behind CSDP efforts. Krasner and Risse (2014: 547) require certain 
preconditions for state-building at the domestic level of the partner country and society to be effective: a solid institutional design, cooperation and coordination (task complexity) and a high level of local political ownership on the structure, content and direction of the reform process (legitimacy). Local ownership poses a particularly challenging international-domestic nexus (mirroring the domesticinternational nexus inside the EU). If ownership is not ensured from the outset but has to be 'produced' or enhanced through peacebuilding and SSR, a long-term engagement to socialise local partners in favour of EU norms and values to generate legitimacy for EU engagement on the partner side is needed (European Commission and HR/ VP, 2016: 12).

Unless building on a solid national peace agreement and conflict settlement, the EU will have to choose local partners and will be challenged by international partners engaged in local conflicts by the question of legitimacy (Mac Ginty and Richmond, 2013; Ejdus and Juncos, 2018). This is visible in all our three cases, and results in problematic political deals, especially since in all our cases the necessity to build up hard security capacity of the central government was considered necessary but undermined civilian approaches to SSR and run counter to the premises of critical conflict transformation. The indispensable choice of local partners is likely to challenge existing 'local' power structures across all levels of government (see paradox 1 in Bøås and Rieker, 2019: 15). Involving local stakeholders in terms of an inclusive approach to a continuous reform process may foster resistance of locals due to infringements on their 'traditional' political influence and power and, in consequence, question the effectiveness of reform efforts and EU efforts. ${ }^{30}$

In sum, policy evaluations of SSR efforts and specifically CSDP missions reveal several strengths, weaknesses but also challenges. Factors constraining EU policy effectiveness are located on all levels of policy-making, the output and outcome levels of policy formulation by member states and EU institutions as much as the level of implementation in the field. However, ultimately political responsibility and accountability in a democratic polity like the EU reside with the 'government' and ultimately in the realms of intergovernmental foreign policy-making of member states.

A critical reflection provides good reasons to question whether the EU's SSR interventions are indeed primarily meant to solve 
political conflicts and social violence in the extended neighbourhood. On the politics level, the EU and member states are raising suspicion that they are more interested in a demonstration of a global role for the Union, rendering '( $h$ )oisting the EU colours and gaining in profile as an international actor ... often more important than immediate problem-solving!' (Peters, 2016: 265; see European Parliament, 2015: 7f). Starting with formulating elusive policy goals - from the strategic to the operational level - continuing with missing or flexible benchmarks for success, and lacking an organisational approach to learning leads us to doubt whether EU crisis response policy is capable to deliver beyond political lipservices. Defining mandates and strategy broadly and abstractly enables the EU to construct success narratives for the public. Whether in arms control matters, environmental standards, the fulfilment of the Copenhagen criteria for accession to the EU, or in EU in crisis response policy, monitoring may be done collectively and from diverse (external) agencies, but the 'certification of compliance' or effectiveness so far, unfortunately, remains a prerogative of politics and thus of political expediency. The interventionary character of CSDP missions pursuing mostly EU-centric reforms, the lack of conflict sensitivity and understanding of the root causes of conflicts it seeks to solve and the incoherence of its comprehensive approach in sum lead to, the EU's crisis response policy in practice being stuck between conflict transformation and conflict resolution approaches. The EU's rhetorical awareness and ambition that legitimate, effective and sustainable conflict response policies ought to be geared towards critical crisis transformation require a critical practice turn.

\section{Notes}

1 See literature review in Peters, 2016: 6-25.

2 See, for details, Chapter 2, this volume, and the section, 'Theory and concepts'.

3 See Beswick and Jackson, 2011: 251. As of April 2019, the EU has launched 34 missions and operations (see EEAS, 2019).

4 These categories and their specific characteristics are established in Chapter 2, this volume. 
5 The perception studies, following a close to identical design, were all carried out in 2017. The questionnaire was adapted to local contexts, including local languages. In Afghanistan in 2017 a total of three hundred respondents from three categories with a hundred each, namely: people in the community with EUPOL-trained police assigned in the area, stakeholders from implementing ministries, and police officers involved or who were mentored/trained by EUPOL were interviewed and filled out the questionnaires. In Iraq in 2017, 295 questionnaires were answered across four governorates: Erbil, Sulaimaniah, Dohuk and Kirkuk covering proportionally refugees, internally displaced persons, local governments and civil society organisations (CSOs) with 50.5 per cent being direct beneficiaries of the EU's involvement, and 35 per cent were female. In Mali in 2017, 105 participants with 24 per cent being female with police and gendarmerie and local beneficiaries of CSDP missions as respondents.

6 Between 2016 and 2019, interviews were conducted with staff of the European Parliament, EC, the EEAS and mission members as well as EU Member State representatives in the Committee for Civilian Aspects of Crisis Management.

7 For the operationalisation of categories, criteria and indicators see Peters et al., 2018: annex 7.

8 See for the same EU practice, for example, regarding the EU Police Mission in Bosnia and Herzegovina (EUPM BiH) and EUPOL Proxima (Tolksdorf, 2014: 68).

9 For an overview on EU policy features see Peters et al., 2018: annex 6.

10 Interview with EU officials in Brussels, 6-8 March 2017.

11 Several projects relate to the framework of the 'Sahel Window' of the European Trust Fund. See Boutillier, 2017: 190.

12 Interview with former EUPOL mission member, 2018.

13 For a more critical assessment see Korski, 2010: 237; Troszczynska-van Genderen, 2010: $17 \mathrm{f}$.

14 For a detailed conceptualisation of the comprehensive approach, see Bátora et al., 2016: 6.

15 Conflict sensitivity in the context of EU crisis response implies recognising the complexity and multilayeredness of conflict, and that different groups in conflict have differing perceptions of the root causes of conflict and legitimate actions and agents. For details, see Bátora et al., 2016: 31f.

16 Interview with EU officials in Brussels, 7 March 2017.

17 For details variants of ownership as defined in EU documents, see Heinemann, 2017: annex 4.6.

18 For another example for such a discrepancy between EU delivery and local expectations in the field of training and equipment in the case of Libya, see Loschi et al., 2018: 6. 
19 Like statistics, indices have to be used with care, see Munck and Verkuilen, 2002; Davis et al., 2015.

20 See World Bank Group, 2018. This index comprises six dimensions of governance: voice and accountability, political stability and absence of violence/ terrorism, government effectiveness, regulatory quality, rule of law, and control of corruption.

21 The country has increased its score in Voice and Accountability, Political Stability and Absence of Violence/Terrorism and Control of Corruption. See World Bank Group, 2018.

22 At the beginning of EUTM engagement, FAMa consisted of around 10,000 soldiers. In January 2016, the president announced that due to the additional recruitment of 10,000 voluntary soldiers, this number is aimed to increase to 20,000 until 2019. See Malijet, 2017.

23 NTM-A encompassed about 558 mentor teams with up to 4,000 trainers and an annual budget of US $\$ 3.5$ billion in 2011 (House of Lords, 2011: 15).

24 'Politics' is here ultimately defined with David Easton as the process of decision-making within a political system authoritatively allocating values for society (here the EU). See Easton, 1965: 96.

25 For overlaps with other expert literature see, for example, Peters, 2016: 265; Dari et al., 2012: 52; Gross, 2013: 23f; Oksamytna, 2011: 10.

26 For the controversy on the impact of external shocks on securitisation processes see, for example, Boswell, 2007: 590-8.

27 Interview with EEAS official in Brussels, 6 March 2017; Bøås and Rieker, 2019: 13, and paradoxes 4 and 5.

28 See also EUNPACK findings in Raineri and Rossi, 2018.

29 See, for example, Belo and Koenig, 2011 on the UN's lack of achievements in Timor-Leste.

30 This has been a long-time concern of peacebuilding and SSR literature. See Schroeder et al., 2014; Stedman, 1997.

\section{References}

Bapir, M.A. (2010) 'Iraq: a deeply divided polity and challenges to democracy-building', Information, Society and Justice Journal, 3(2): 117-125.

Barea, J.C.C. (2013) The Malian Armed Forces Reform and the Future of EUTM. Opinion Document. Vol. 93/2013 (Madrid: Instituto Español de Estudios Estratégicos).

Bátora, J., S. Blockmans, E. Ferhatovic, I. Peters, P. Rieker and E. Stambøl (2016) 'Understanding the EU's crisis response toolbox and 
decision-making processes', EUNPACK Working Paper D.4.1, EUNPACK project.

Bayer Tygesen, C. (2013) 'A cloud over EU's legacy in Afghanistan?' The Europe Center (TEC), https://tec.fsi.stanford.edu/news/a_cloud_over_ eus_legacy_in_afghanistan_20130219 (accessed 26 September 2018).

Belo, N. De Sousa and M.R. Koenig (2011) Institutionalizing community policing in Timor-Leste: Exploring the politics of police reform, Occasional Paper 9 (San Francisco: Asia Foundation).

Beswick, D. and P. Jackson (2011) Conflict, Security and Development: An Introduction (Oxford: Routledge).

Bøås, M. and P. Rieker (2019) EUNPACK Executive Summary of the Final Report \& Selected Policy Recomendations: A Conflict-Sensitive Unpacking of the EU Comprehensive Approach to Conflict and Crisis Mechanisms (Brussels: Centre for European Policy Studies).

Bøås, M., A.W. Cissé, A. Diallo, B. Drange, F. Kvamme and E. Stambøl (2018) 'The EU, security sector reform and border management in Mali', Working paper on implementation of EU crisis response in Mali, EUNPACK Working Paper D.7.4, EUNPACK project.

Börzel, T.A. and T. Risse (2004) 'One size fits all! EU policies for the promotion of human rights, democracy and rule of law', paper prepared for the Workshop on Democracy Promotion, 4-5 October, Center for Development, Democracy, and the Rule of Law, Stanford University.

Boswell, C. (2007) 'Migration control in Europe after 9/11: Explaining the absence of securitization', JCMS: Journal of Common Market Studies, 45(3): 589-610, doi: https://doi.org/10.1111/j.1468-5965.2007.00722.x. Boutillier, C. (2017) 'The security and development nexus', in J. Rehrl (ed.), Handbook CSDP. The Common Security and Defence Policy of the European Union, 3rd edn (Vienna: Federal Ministry of Defence and Sports of the Republic of Austria), 184-192.

Burke, E. (2009) 'The case for a new European engagement in Iraq', FRIDE Working Paper 74 (Madrid: FRIDE).

Carrasco, C. Márquez, C. Churruca Muguruza, and R. Alamillos Sánchez (2016) Case Study: Common Security and Defence Policy (CSDP), Fostering Human Rights among European Policies (FRAME, EU Commission FP7/2007-2013, project no. 320000, Work Package D.10.3) (Leuven: KU Leuven Centre for Global Governance Studies (KUL-GGS)).

Christova, A. (2013) 'Seven years of EUJUST LEX: The Challenge of Rule of Law in Iraq', Journal of Contemporary European Research, 9(3): 424-439.

Cissé, A.W., A. Dakouo, M. Bøås and F. Kvamme (2017) 'Perceptions about the EU crisis response in Mali - a summary of perception studies', EUNPACK Policy Brief D.7.7, EUNPACK project. 
Council of the European Union (2007) Council Joint Action 2007/369/CFSP of 30 May 2007 on establishment of the European Union Police Mission in Afghanistan (EUPOL Afghanistan), Brussels: Council Secretariat, https://op.europa.eu/en/publication-detail/-/publication/80f4fc25-d2324bd2-88a1-42abfd88e823/language-en (accessed 13 March 2020).

Council of the European Union (2012a) Council Conclusions on the Situation in Mali, Brussels: Council Secretariat (14926/12).

Council of the European Union (2012b) Council Conclusions on the Situation in Mali, Brussels: Council Secretariat (17535/12).

Council of the European Union (2013) EU Council Conclusion Iraq, Brussels: Council Secretariat (8680/13), http://eeas.europa.eu/archives/docs/iraq/ docs/iraq_council_2004-08_en.pdf (accessed 10 February 2017).

Council of the European Union (2015) Council Conclusions on the Sahel Regional Action Plan 2015-2020, Brussels: Council Secretariat (7823/15).

Council of the European Union (2016) Council Decision amending and extending Council Decision 2013/34/CFSP on a European Union military mission to contribute to the training of the Malian Armed Forces (EUTM Mali), Brussels: Council Secretariat (6375/16).

Dari, E., M. Price, J. van der Wal, M. Gottwald and N. Koenig (2012) CSDP Missions and Operations: Lessons Learned Processes (Brussels: European Parliament).

Davis, K.E., B. Kingsbury and S.E. Merry (2015) 'Introduction: The localglobal life of indicators: Law, power, and resistance', in S.E. Merry, K.E. Davis and B. Kingsbury (eds), The Quiet Power of Indicators - Measuring Governance, Corruption, and Rule of Law (New York: Cambridge University Press), 1-24.

Djiré, M., D. Sow, K. Gakou, and B. Camara (2017) Assessing the EU's Conflict Prevention and Peacebuilding Interventions in Mali (Bamako: Université de Sciences Juridiques et Politiques de Bamako).

Easton, D. (1965) A Framework for Political Analysis (Englewood Cliffs, NJ: Prentice-Hall, Inc).

Echavez, C. and Q. Suroush (2017) 'Assessment of EU's Response in Afghanistan: Did EU's conflict response through EUPOL deliver as it intended: A review of how EU in general and EUPOL in particular were received and perceived among Afghan stakeholders in Kabul', EUNPACK Policy Brief D.7.6, EUNPACK project.

Ejdus, F. and A.E. Juncos (2018). 'Reclaiming the local in EU peacebuilding: Effectiveness, ownership, and resistance', Contemporary Security Policy, 39(1): 4-27, doi: 10.1080/13523260.2017.1407176.

EEAS (2014a) 'Common Security and Defence Policy: EU Integrated Rule of Law Mission for Iraq (EUJUST LEX-Iraq)' (Brussels: EEAS), 
www.eeas.europa.eu/archives/csdp/missions-and-operations/eujust-lexiraq/pdf/facsheet_eujust-lex_iraq_en.pdf (accessed 6 October 2016).

EEAS (2014b) 'Strengthening the efficiency and credibility of the criminal justice system and enhancing the rule of law' (Delegation of the European Union to Iraq, 26 May).

EEAS (2015) 'Annual 2014 CSDP Lessons Report' (Brusssels: EEAS).

EEAS (2016) 'EU Training Mission in Mali' (Brussels: EEAS).

EEAS (2019) EU Missions and Operations. As part of the EU's Common Security and Defence Policy (CSDP) (Brussels: EEAS).

European Commission (2014) 'Multiannual Indicative Programme for Iraq 2014-2017’, Brussels (20726919).

European Commission (2015) 'European Union - West Africa - Regional Indicative Programme 2014-2020'.

European Commission and EEAS (2014) 'Multi-Annual Indicative Programme 2014-2020', Brussels.

European Commission and HR/VP (2016) Joint Communication to the European Parliament and the Council. Elements for an EU-wide strategic framework to support security sector reform, (JOIN2016/31 final) (Brussels: European Commission).

European Court of Auditors (2015) The EU Police Mission in Afghanistan: Mixed Results, Special Report No. 7/2015 (Luxembourg: Publications Office of the European Union).

European Parliament (2015) 'Report on the implementation of the Common Security and Defence Policy (based on the Annual Report from the Council to the European Parliament on the Common Foreign and Security Policy)' (Brussels: European Parliament (A8-0054/2015)).

European Union HR/VP (2016) Shared Vision, Common Action: A Stronger Europe. A Global Strategy for the European Union's Foreign and Security Policy (Brussels: EU).

EU Training Mission in Mali (EUTM) (2018) 'Factsheet' (July) (Brussels: EUTM), https://eutmmali.eu/wp-content/uploads/2018/07/EUTM_Mission_Factsheet_31July18_EN.pdf (accessed 7 August 2019).

Fuhrmann, J. (2016) 'The response has been very positive', 13 January, www.deutschland.de/en/topic/politics/peace-security/the-response-hasbeen-very-positive (accessed 4 September 2018).

George, A.L. (1979) 'The causal nexus between cognitive beliefs and decision-making behavior: The "Operational Code" belief system', in L.S. Falkowski (ed.), Psychological Models in International Politics (Boulder, CO: Westview Press), 95-124.

Gross, E. (2013) Assessing the EUs Approach to Security Sector Reform (SSR) (Brussels: European Parliament). 
Hänggi, H. (2004) 'Conceptualising security sector reform and reconstruction', in A. Bryden and H. Hänggi (eds), Conceptualising Security Sector Reform and Reconstruction (DCAF Geneva / Münster: LIT Verlag).

Hawkins, D.G., D.A. Lake, D.L. Nielson and M.J. Tierney (2006) 'Delegation under anarchy: states, international organizations, and principalagent theory', in D.G. Hawkins, D.A. Lake, D.L. Nielson and M.J. Tierney (eds), Delegation and Agency in International Organizations (New York: Cambridge University Press), 3-38.

Heider, T., M. Kleine and I. Peters (2004) 'Discussion paper: Options for evaluating CFSP effectiveness' (unpublished manuscript).

Heinemann, R. (2017) 'The European Union's crisis response in the extended neighbourhood: The EU's output effectiveness in the case of Mali', EUNPACK Working Paper D.7.1, EUNPACK project.

Hettne, B. and F. Söderbaum (2005) 'Civilian power or soft imperialism? The EU as a global actor and the role of interregionalism', European Foreign Affairs Review, 10(4): 535-552.

House of Lords (2011) European Union Committee. The EU's Afghan Police Mission, London, https://publications.parliament.uk/pa/ ld201011/ldselect/ldeucom/87/8704.htm (accessed 14 February 2020).

Human Rights Watch (2017) 'Mali: Unchecked abuses in military operations', 8 September, www.hrw.org/news/2017/09/08/mali-uncheckedabuses-military-operations (accessed 12 March 2018).

Janning, J. (2005) 'Leadership coalitions and change: The role of states in the European Union', International Affairs, 81(4): 821-833.

Kassim, H. and A. Menon (2003) 'The principal-agent approach and the study of the European Union: Promise unfulfilled?' Journal of European Public Policy, 10(1): 121-139.

Korski, D. (2010) 'EUJUST LEX (Iraq)', in G. Grevi, D. Helly and D. Keohane (eds), European Security and Defence Policy: The First 10 Years (1999-2009) (Paris: EU Institute for Security Studies), 231-242.

Krasner, S.D. and T. Risse (2014) 'External actors, state-building, and service provision in areas of limited statehood: Introduction', Governance, 27(4): 545-567, doi: 10.1111/gove.12065.

Lebovich, A. (2017) 'Serious questions remain over G5 Sahel military force', European Council on Foreign Relations, Commentary, 16 June, www.ecfr.eu/article/commentary_serious_questions_remain_over_g5 sahel_military_force_7300 (accessed 11 March 2018).

Loschi, C., L. Raineri and F. Strazzari (2018) 'The implementation of EU crisis response in Libya: Bridging theory and practice', EUNPACK Working Paper D.6.2, EUNPACK project. 
Mac Ginty, R. (2010) 'Hybrid peace: The interaction between top-down and bottom-up peace', Security Dialogue, 41(4): 391-412, doi: 10.1177/0967010610374312.

Mac Ginty, R. and O.P. Richmond (2013) 'The local turn in peace building: A critical agenda for peace', Third World Quarterly, 34(5): 763-783, doi: 10.1080/01436597.2013.800750.

Malijet (2017) 'Les forces armées maliennes aujourd'hui', http://malijet. com/a_la_une_du_mali/187481-les-forces-arm\% C3\% A9es-maliennes-aujourd\%E2\% 80\%99hui.html (accessed 18 September 2018).

Martin, L. (1993) 'The rational state choice of multilateralism', in J.G. Ruggie (ed.), Multilateralism Matters: The Theory and Praxis of an Institutional Form (New York: Columbia University Press), 91-121.

Mohammed, K., D. Ala'Aldeen and K.M. Palani (2017) 'Perceptions about EU crisis response in Iraq - a summary of perception studies', EUNPACK Policy Brief D.7.5, EUNPACK project.

Munck, G.L. and J. Verkuilen (2002) 'Conceptualizing and measuring democracy: Evaluating alternative indices', Comparative Political Studies, 35(1): 5-34, doi: https://doi.org/10.1017/S1537592711000880.

Nicolaïdis, K., B. Sébe and G. Maas (eds) (2015) Echoes of Empire. Memory, Identity and Colonial Legacies (London: I.B. Tauris Publishers).

OECD (2018) States of Fragility 2018 (Paris: OECD Publishing).

Øhrgaard, J.C. (2004) 'International relations or European integration: Is the CFSP sui generis?', in B. Tonra and T. Christiensen (eds), Rethinking European Union Foreign Policy (Manchester: Manchester University Press): 26-44.

Okemuo, G. (2013). 'The EU or France? The CSDP Mission in Mali the Consistency of the EU Africa policy', Liverpool Law Review, 34(3): 217-240.

Oksamytna, K. (2011) 'The European Union Training Mission in Somalia: Lessons learnt for EU Security Sector Reform', Istituto Affari Internazionali. IAI Working Papers, 11(16): 1-16.

Peters, I. (ed.) (2016) The European Union's Foreign Policy in Comparative Perspective: Beyond the 'Actorness and Power' Debate (London and New York: Routledge).

Peters, I. (2017) 'The European Union's crisis response in the extended neighbourhood: The EU's output effectiveness in the case of Iraq', EUNPACK Working Paper D.7.1, EUNPACK project..

Peters, I., E. Ferhatovic, R. Heinemann, S. Berger and S.M. Sturm (2018) 'European Union's crisis response in the extended neighbourhood: Comparing the EU's output effectiveness in the cases of Afghanistan, Iraq and Mali, EUNPACK Working Paper D.7.1 (part 4), EUNPACK project. 
Raineri, L. and A. Rossi (2018) 'The security-migration-development nexus in the Sahel: A reality check', in B. Venturi (ed.), The SecurityMigration-Development Nexus Revised: A Perspective from the Sahel (Rome: Istituto Affari Internazionali), 13-34.

Richmond, O., S. Pogodda and R. Mac Ginty (2016) 'Towards critical crisis transformation', EUNPACK Working Paper D.3.2, EUNPACK project.

Schimmelfennig, F. and U. Sedelmeier (eds) (2005) The Europeanization of Central and Eastern Europe (Ithaca, NY and London: Cornell University Press).

Schroeder, U.C., F. Chappuis and D. Kocak (2014) 'Security sector reform and the emergence of hybrid security governance', International Peacekeeping, 21(2): 214-230, doi: 10.1080/13533312.2014.910405.

Sedra, M. (2013) 'The hollowing-out of the liberal peace project in Afghanistan: The case of security sector reform', Central Asian Survey, 32(3): 371-387, doi: 10.1080/02634937.2013.843387.

Skeppström, E., C. Hull Wiklund and M. Jonsson (2015) 'European Union Training Missions: Security sector reform (SSR) or counter-insurgency by proxy?', European Security, 24(2): 353-367, doi: 10.1080/ 09662839.2014.972382.

Stedman, S.J. (1997) 'Spoiler problems in peace processes', International Security, 22(2): 5-53, doi: 10.2307/2539366.

Suroush, Q. and E. Ferhatovic (2017) 'Assessing EUPOL Impact on Afghan Police Reform (2007-2016)', EUNPACK Working Paper D.7.3, EUNPACK project.

The Economist Intelligence Unit (2017) Mali: Country Report (London, New York, Hong Kong).

The Economist Intelligence Unit (2018) Democracy Index 2017. Free speech under attack (London).

The Economist Intelligence Unit (2019) Democracy Index 2019 (London). Thomas, D.C. (2012) 'Still punching below its weight? Coherence and effectiveness in European Union foreign policy', JCMS: Journal of Common Market Studies, 50(3): 457-474, doi: https://doi.org/10.1111/ j.1468-5965.2011.02244.x.

Tolksdorf, D. (2014) 'Incoherent peacebuilding: The European Union's support for the police sector in Bosnia and Herzegovina, 2002-8', International Peacekeeping, 21(1): 56-73, doi: 10.1080/13533312.2014.885710.

Transparency International (2018) 'Corruption Perceptions Index 2017', www.transparency.org/news/feature/corruption_perceptions_ index_2017 (accessed 14 August 2018).

Troszczynska-van Genderen, W. (2010) Human rights challenges in EU civilian crisis management: The cases of EUPOL and EUJUST LEX, Occasional Paper 84 (Paris: EU Institute for Security Studies). 
Tull, D.M. (2017) Mali und G5: Ertüchtigung des Sicherheitssektors. Politische Hindernisse für eine effektive Kooperation der Regierung und ihrer Partner, SWP-Aktuell 76 (Berlin: SWP).

Underdal, A. (2004) 'Methodological challenges in the study of regime effectiveness', in A. Underdal and O.R. Young (eds), Regime Consequences: Methodological Challenges and Research Strategies (London: Kluwer Academic), 27-48.

United Nations (2015) 'Concluding observations on the fifth periodic report of Iraq' (New York: UNHRC (CCPR/C/IRQ/CO/5)).

United Nations (2016) 'Concluding observations on the combined sixth and seventh periodic reports of Mali' (New York: UNHRHC Committee on the Elimination of Discrimination against Women (CEDAW/C/ $\mathrm{MLI} / \mathrm{CO} / 6-7 \mathrm{MALI})$ ).

United Nations (2017) 'Concluding observations on the second periodic report of Afghanistan' (New York: Office of the UNHCHR, Committee against Torture (CAT/C/AFG/CO/2)).

Vermeij, L. (2015) 'MINUSMA: Challenges on the ground,' Policy Brief 19 (Oslo: NUPI).

World Bank Group (2018) 'Worldwide Governance Indicators', http://info. worldbank.org/governance/wgi/\#reports (accessed 12 March 2018).

Youngs, R. (2004) 'Europe and Iraq: From stand-off to engagement?', CEPS Working Documents 216 (Brussels: Centre for European Policy Studies).

Zürn, M. (1993) 'Problematic social situations and international institutions - on the use of game theory in international politics', in F.R. Pfetsch (ed.), Inaugural Pan-European Conference: International Relations and Pan-Europe (Münster and Hamburg: LIT-Verlag), 63-84. 